\title{
AN ARTICLE ON IMPORTANCE OF SOFTWARE TECHNOLOGIES IN BUSINESS AND MANAGEMENT SCIENCE
}

\author{
Dr. Ajay Nanaji Saratkar \\ Asstt. Professor, \\ Yashwantrao Gudadhe Patil Memorial College of Arts, Commerce and Science \\ Nagpur
}

\begin{abstract}
As per title of the paper now a day's machines like mobile, computer, Lap-top with higher configurations are enter into the market for their daily needs. Developers tie together different tools to develop programs for specific commerce needs that take less time to perform various tasks, improve efficiency and cut costs. Now a days, every business uses business software for fast solutions. Business in today's world need dedicated software for successful operation and growth. Lot of the players expand their business with the help of software technologies thousands of software's available on the play store with free of charge. The easiest and most convenient way is to use project management software with online collaboration. There are various types of software to help in the business needs. This Paper studying various online businesses which are linked to the play stores, emails, applications with their potential clients via business management software platforms. There are many hosting companies that provide dedicated email ids and websites domains which help in managing the clients' emails and notifying them whenever needed.
\end{abstract}

KEYWORDS: Software, Applications, CRM, Management, software development, promotion

\section{INTRODUCTION}

In today's world of information technology, Computers, IT systems and the Internet are becoming essential for many of our everyday tasks. Therefore, having a web (www.) presence has become mandatory to stay competitive in the business. Use of business software has also become necessary to ensure that you are competing with the world. Mobility and clarity of machine is the heart part of the expansion in business. Indian and Indians are lot of the ahead in designing and developing software in ecommerce field. Management information system working from
India for various countries services and support designed developed from India. Well-known Multinational companies such as cognizant, CapGemini, TCS, aloha, persistence are spread their business from India. A city such as Pune, Mumbai, Delhi, Bangalore, Hyderabad, Nagpur, Kolkata and Chennai earns much more revenue for India.

Use of software is important for automation of the organization's tasks as well as reporting the progress or lags in the organization's activities. This improves company's efficiency and effectiveness of the company's activities. The software reduces the workload and automation of activities. It also assists in elimination of human errors, as a result, improves effectiveness and consistency.

There are various types of business software commonly used by companies. Software is responsible for accomplishing different tasks. One of the most important business software for any organization is the payroll system. This software is important for managing payments within the organization for employees and contractors. This is able to calculate the payment and tax deductions for each and every employee in the organization.

The other crucial software for companies is the invoice and billing software. The software is easy to use and handle a number of transactions in their daily activities. You need to enter specific details of the client from the database and the invoice is ready to be sent to the clients.

Business Software Solutions provides business productivity that is available in different types and modules. The most important and motivating factors for using the Business Software are increasing the productivity and profits.

\section{REVIEW OF LITERATURE}

1) Why technology important in business? By:Neil Kokemuller by: Jayne Thompson LLB,LLM ，Updated July 29,2019.Both 
are concentrated on Different industries and companies rely on technology in different ways, but some benefits of technology in business include improved communication, optimized production, inventory Information Technology \& Its Uses in Business Management

2) By Nicky LaMarco; Updated October 23, 20management and financial recordkeeping. :Concentrated on the Articles1)Five IT Functions in an Organization2)Information Technology \& Its Uses in Business Management3)Advantages of Using Computers in Business4)Benefits of a Computer to an Accountant

3) Website, Information-technologybusiness-today: Just about every business you can think of uses computers in one way or another to carry out its functions. From generating reports to communicating with clients, computers do a lot for the efficiency with which a business is run. The computer has brought the business a long way from the age of pen and paper, and folders stored in dusty storage compartments. The uses of a computer are simply endless.

\section{RESEARCH METHODOLOGY}

Significance of Study:

* Importance of this study is to show consequence of use software in business.

* Expansion of businesses with software technologies

\section{Objectives:}

$>$ To study on business software and its security and reliability

$>$ To study on utilization percentage of software and its awareness in between consumers.

$>$ To study on time effectiveness of software technologies and its reliability.

$>$ To study on CRM and ERP services of business models derive suggestion \& to improve the quality for Expansions.

Data collection and scope:

* Primary: Questionnaire designed for companies, business man, consumers, developers (Each 25 samples) total 100 samples combined and taken for study.

* Questionnaire structured and replies taken from various elements and calculated for title satisfaction.

* Secondary: Study based on collected information of different company's reports from first and second level metro-Politian cities (Pune,Nagpur,Kolhapur,NaviMumbai)

* Businesses in second level metro-Politian cities uses ERP and store app for transactions.

* Business support with mobility devices such as laptop, mobile phones, iPods etc

* Questionnaire:

Designed structured 10 (8 considered) Questions for primary survey and collected answers and from domestic industrial, business \& IT field related persons: As per questionnaire design table number 1 shows symptoms of objectives and its outcomes.

TABLE NO: 1: Software (technology) in Business and management science

\begin{tabular}{|l|l|l|l|l|l|l|}
\hline $\begin{array}{l}\text { S.N } \\
\cdot\end{array}$ & Particulars in Questionnaires & S.A. & A. & Null & D.A. & SDA \\
\hline 1 & Data plays major role in organisation with security & 75 & 15 & 5 & 5 & 0 \\
\hline 2 & Computerised and atomization sector plays imp role & 80 & 10 & 5 & 5 & 0 \\
\hline 3 & Software technology is promising one for customer & 75 & 10 & 10 & 3 & 2 \\
\hline 4 & Companies decide about software and its timely changes & 55 & 20 & 10 & 10 & 5 \\
\hline 5 & Software provides best services to all stake holders & 75 & 15 & 5 & 3 & 2 \\
\hline 6 & $\begin{array}{l}\text { CRM and Accounting software's are performing } \\
\text { accurately in industries }\end{array}$ & 65 & 15 & 10 & 5 & 5 \\
\hline 7 & $\begin{array}{l}\text { Software minimizes exp. cost of business and } \\
\text { Gets profit. }\end{array}$ & 73 & 12 & 10 & 3 & 2 \\
\hline 8 & $\begin{array}{l}\text { software application for both small as well as large } \\
\text { businesses as these applications speed up the process }\end{array}$ & 68 & 12 & 10 & 8 & 2 \\
\hline
\end{tabular}

(SA: Strongly agree, A: Agree, DA: Disagree, SDA: Strongly disagree)

Above table shows: responses from various stake holders of business and management sector utilizes software and away from software technology.

* Portrayal : 
International Journal of Engineering Applied Sciences and Technology, 2019

Vol. 4, Issue 4, ISSN No. 2455-2143, Pages 291-294

Published Online August 2019 in IJEAST (http://www.ijeast.com)

Line of chart for Effectiveness of software technology in business and management sector:

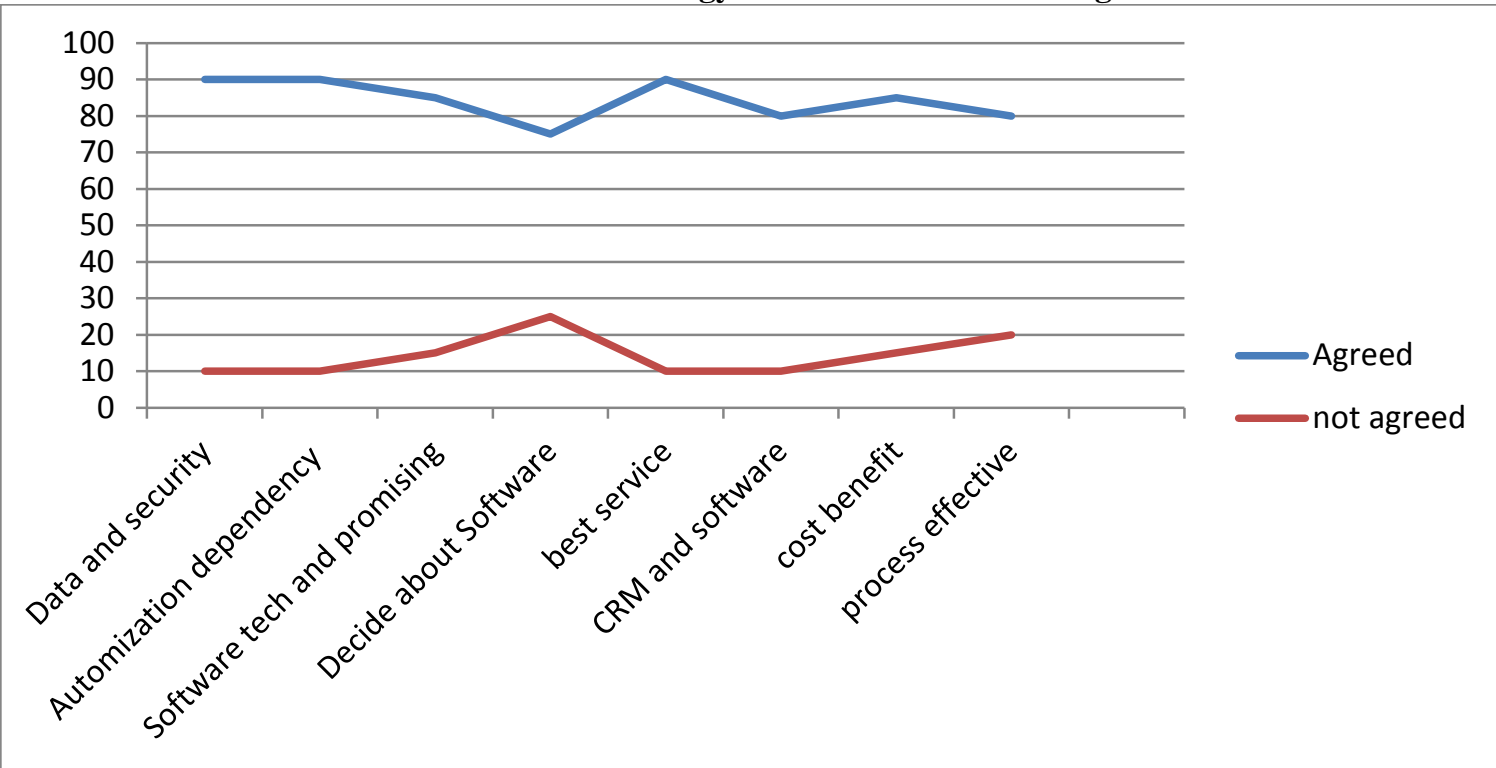

Interpretation: For 100 samples line of chart showing response from stakeholders concern with software technologies

\section{EXPLANATION}

\section{Security and reliability:}

In today's time, as we all know, data plays a major role in any organization. Out of all samples (90\%) are agreed on data its importance and security. If its security is cracked originations faces big problems in business. By choosing Software's, you automatically enter into a fully secured environment when not even a single bit of data would be at a risk of getting affected by any undesired mean. At each stage Software ensures customers for data security and reliability by using highly secured environment while developing the project.

Time Efficient:

Before some years ago all atomization is depending on electrical and mechanical system but now software and computerised support keeps its promise to the customer for developing the project in the pre-mentioned time. Due to this $85 \%-90 \%$ are Companies decide about Software and automatic technologies. They will not have to wait for ages to get their own product deployed to client.

Service provider: Software's and supporting technologies provides with the best customer service. $90 \%$ users are techno-savvy and uses atomization Internet and wireless technologies in maintaining their daily routines and work. It provides with the best customer relationship that will ever have. It encourages business participation in the development process too. It will also give them a draft of the product for their review before delivering the final result. This increases the scope of continuous improvisation. Feedback collection and data analysis done in regular manner automatically and results were reaches to the proper tables for future enhancement.

- CRM (Customer Relationship Management) : As the name suggests, helps a firm to keep a track of the customers and the relationship with them. It is very helpful software when it comes to large number of clients as it not only helps to keep an eye on the number of clients that a firm has, but it also helps in managing the appointments with them. Lot of the companies are taken their backups from apps and collect feed backs with applications and expose their backups on face book and other social sites for promotion of products. As per sample of survey $65 \%$ are strongly agreed upon CRM system of companies its percentage is low because lot of the customers were not responded properly. Also, it reminds about the follow ups even when the professional relationship has ended it see if your valuable former customers are interested for any further projects.

Various accounting software and important business software for proper management were entered for calculation of revenues and expenditures that ultimately give an overview of a business failure or success. It is a process of collecting, summarizing and analyzing the financial data of an organization. Business 


\section{International Journal of Engineering Applied Sciences and Technology, 2019 Vol. 4, Issue 4, ISSN No. 2455-2143, Pages 291-294 \\ Published Online August 2019 in IJEAST (http://www.ijeast.com)}

software allows managing business better, efficiently and easily. However, choosing the best software is the most important part while purchasing the business software for your business needs. In fact, a lot of software is available in the market with different features. You need to calculate your needs to decide the most appropriate software solution for your business. In fact, it is becoming a norm to purchase an accounting software application for both small as well as large businesses as these applications speed up the process.

\section{CONCLUSION}

In a way, software can be seen as a simplification of a process. All businesses will have administration and customer service packages that help them perform day-to-day tasks without heaps and stacks of paperwork and other information. Software and data help computers run a business and help you and your employees keep track of everything. If a piece of software isn't helping you store and categorize information, it is helping you do something.

Software exists for creative production purposes as well. We write with word processing software that matches our keyboard inputs to create an output of documentation. We have video editing software that can trim and edit films, and audio software that can do the same with audio and music. Picture editing tools create artwork from imagery. We have software that creates as well as categorizes.

\section{RECOMMENDATIONS}

Computer technology and its mobility handle management Tasks Easily but network and frequency range required properly. Man, money, machine and time period are heart part of industrial sector affected on cost and computerisation saves it.

Due to accuracy and efficiency computerisation is essential in all sector but skilled workers are required. Computerisation sector is safe and sound in data storage but proper security may be required. Due to powerful network sector mistakes recovered vastly and keep concentration on business promotion and progress but accurate technical support required.

\section{REFERENCES}

1) Paruchuri, Srikanth., Awate, Snehal (2017) "Organisational knowledge networks and local search: the role of intra-organisational inventor networks", Strategic Management Journal, 38 (3), 657-675

2) Prof. Krume Nikoloski $\mathrm{PhD} 1$ Faculty of Economics at University "Goce Delcev" Stip, Republic of Macedonia, "The Role of Information Technology in the Business Sector" International Journal of Science and Research (IJSR) ISSN (Online): 2319-7064 vol:3 issue 12 December 2014, page no 303-308.

3) ] Dedrick, J., Kraemer, K. L., \& Xu, S. (2004). Information technology payoff in e-business environments: An international perspective on value creation of e-business in the financial services industry. Journal of Management Information Systems, 21(1), 17- 54. [8] Gerstein, M., \& Riesman, H. (1982).

4) Creating Competitive Advantage with Computer Technology. Journal of Business Strategy, 3(1), 5360. [9] Grant, R.M. (1991). Role Of ICT In Research Information Technology Essay

5) https://www.ukessays.com/essays/2552 words (10 pages) Essay in Information Technology.

6) Yasemin Bal, Esin Ertemsir Yıldız Technical University, (2012), The importance of using human resources information systems (HRIS) and a research on determining the success of (HRIS), Make learn international conference, ISBN/978-961-6813-10-5 page no(53-63)

7) Why technology important in business? By:Neil Kokemuller by: Jayne Thompson LLB,LLM , Updated July 29,2019

8) By Nicky LaMarco; Updated October 23, 2018, management and financial record-keeping. page (home 1-10)

9) S.M.Kundishora (Zimbabwe Academic and research network) The Role of Information and Communication Technology ICT) in Enhancing Local Economic Development and Poverty Reduction (Page no 1-17) 